\title{
Indonesia's Dilemma in Efforts to Disseminate The Covid-19 Vaccine (Rights and Obligations of the State for Citizens) and The Spread of Fake News That Disrupt Rule Enforcement
}

\author{
Amiruddin Pabbu ${ }^{1}$ Patawari $^{2}$, Mira Nila Kusuma Dewi ${ }^{3 *}$ \\ 1, 2, 3, Faculty of Law Indonesia Timur University, Makassar, Indonesia \\ *E-mail: miranila@gmail.com
}

\begin{tabular}{l}
\hline Article Info \\
\hline Keywords: \\
Vaccine Covid-19; \\
Government's \\
Obligation; People's \\
Right; Hoax. \\
DOI: \\
10.47268/sasi.v27i4.679 \\
\hline
\end{tabular}

\begin{abstract}
The purpose of this study is to explain the effort of Indonesian government to fulfill its obligation towards its people's right of health in this pandemic covid-19 situation that is by spreading the covid-19 vaccine on one side and people's spreading fake information about covid-19 on the other side. The research method used is normative legal research. The result of this study shows besides the effort of Indonesian government to manage the pandemic situation, there are so many hoaxes about the pandemic that influence people to object the vaccine. Therefore people are advised to really careful in receiving those information by sorting and choosing the correct information.
\end{abstract}

\section{A. INTRODUCTION}

The Covid-19 pandemic on global economic developments has an influence not only on the world of economy and investment, but also correlates with aspects of legal development ${ }^{1}$. The Constitution of the Republic of Indonesia, namely the 1945 Constitution, adopts the principles of human rights, particularly the right to health. Article $28 \mathrm{H}$ paragraph (1) states "Everyone has the right to live in physical and spiritual prosperity, to have a place to live, and to have a good and healthy living environment and have the right to obtain health services."

Corona Virus Disease-19 (COVID-19) has a significant impact on all aspects of human life in the world, especially in Indonesia which is very large in area and has a large population (around 267 million people) with different kinds of professions ${ }^{2}$. The current state of the COVID-19 pandemic continues to increase, of course, indicating that there is a health emergency situation, so appropriate steps are needed. Comprehensive handling is needed regarding the challenges faced in fulfilling the right to health during the COVID-19 pandemic. In general, the majority of Indonesian people are likely to entrust health services to the Government of the Republic of Indonesia, this is also supported by the private sector which has

1 Saija, R., \& Sudiarawan, K. A. (2021). Perlindungan Hukum Bagi Perusahaan Debitur Pailit dalam Menghadapi Pandemi Covid 19. Batulis Civil Law Review, 2(1), 66-77.

2 Kunarso, K., \& Sumaryanto, A. D. (2020). Eksistensi Perjanjian Ditengah Pandemi Covid-19. Batulis Civil Law Review, 1(1), 33-46.

402 |S A S I Volume 27 Issue 4, October-December 2021 
an important role, ranging from providing health services, producing medical goods and trading.

One of the treatments for the COVID-19 pandemic is the provision of the COVID-19 vaccine to all Indonesians. ${ }^{3}$ The COVID-19 vaccination is an effort to reduce the number of cases of infection with the SARS-CoV-2 virus that causes COVID-19 disease.

The government's efforts to maintain public safety and maintain economic stability, in the spread of COVID-194, the government has issued regulations for handling COVID-19 in the form of Law no. 6 of 2018 concerning Health Quarantine which came into effect on August 8,2018. This rule is the legal basis for giving COVID-19 vaccines to citizens to break the chain of transmission of the COVID-19 virus and provide health protection for the entire community.

The Indonesian government's efforts to fulfill the right to the health of its citizens are still being underestimated because there is still a lot of fake news spreading about the COVID-19 vaccine. This fake news led to the pros and cons in the community regarding the provision of the COVID-19 vaccine. Many people do not believe in the existence of COVID-19 and refuse to be given the COVID-19 vaccine. Preferably, the administration of this vaccine is an effort to protect the public to minimize symptoms when exposed to the COVID-19 virus and to achieve herd immunity to prevent the spread of the disease.

Departing from the government's efforts to fulfill citizens' rights to health on the one hand and the opinions of the pros and cons to the rejection of the COVID-19 vaccine on the other hand, this paper examines the government's efforts to spread the COVID-19 vaccine and the spread of fake news that interferes with enforcement of regulations related to handling COVID19.

\section{B. RESULTS AND DISCUSSION}

The Government of the Republic of Indonesia provides COVID-19 vaccines to the entire community as an effort to fulfill its obligations in implementing health rights for the community according to the 1945 Constitution article $28 \mathrm{H}$ paragraph (1). ${ }^{5}$ This article stipulates that "Everyone has the right to live in physical and spiritual prosperity, to have a place to live, and to have a good and healthy environment and have the right to obtain health services." The community's right to obtain health services is included in the community's right to get the COVID-19 vaccine. The right to public health is also in accordance with the legal principle of salus populi suprema lex, where the safety of the people is the highest law for a country. ${ }^{6}$

This COVID-19 vaccine is also given to the community in the context of implementing Health Quarantine based on the KK Law. ${ }^{7}$ Health Quarantine in the Act is intended as an effort to prevent and ward off the entry and exit of diseases and/or public health risk factors that have the potential to cause public health emergencies. ${ }^{8}$ So, COVID-19 vaccination is an effort to prevent and ward off the entry and exit of diseases and/or public health risk factors that have

\footnotetext{
3 Ariati Dewi, Radhiya Bustan, "Sosialisasi Vaksinasi COVID-19 dan Protokol Kesehatan 7 M Sebagai Upaya Pencegahan Penyebaran Virus COVID-19”, Artikel Hasil Pengabdian kepada Masyarakat, Seminar Nasional Penelitian dan Pengabdian kepada Masyarakat) Tahun 2021, p. 1, https://repository.ummetro.ac.id/files/artikel/3288.pdf, accessed at 12 September 2021.

4 Taun, T., \& Nugraha, A. (2020). Penerapan Hukum dalam Pemutusan Hubungan Kerja dan Kebijakan Bank Terhadap Debitur yang Terdampak Pandemi Covid-19. Batulis Civil Law Review, 1(1), 24-32.

5 Pratama, A. M. (2021, July). Pemenuhan Vaksinasi Covid-19 sebagai Hak atas Kesehatan bagi Masyarakat Adat di Indonesia. In Seminar Nasional Hukum Universitas Negeri Semarang (Vol. 7, No. 1, pp. 219236).

6 Ibid, p. 222-223

7 Raines Wadi, "Keharusan Vaksin dan Hak atas Kesehatan", https://news.detik.com/kolom/d5333213/keharusan-vaksin-dan-hak-atas-kesehatan, accessed at 6 September 2021.

${ }^{8}$ Article 1 paragraph (1) of the Law of the Republic of Indonesia Number 6 of 2018 concerning Health Quarantine

403 |S A S V V l um e 27 Is sue 4, October-December 2021
} 
the potential to cause public health emergencies.

COVID-19 vaccination is the administration of a vaccine that is specifically given in order to actively generate or increase a person's immunity against a disease, so that if something is exposed to the disease it will not get sick or only experience mild illness and will not become a source of transmission. ${ }^{9}$ This vaccination is an obligation for the community as participation in the Health Quarantine program. ${ }^{10}$ Community obligations in this case can be interpreted as something that must be carried out by the community not only to protect themselves but also to protect others. Therefore, the public not only has the right to health with the Covid-19 vaccine according to the constitution, but this COVID-19 vaccination also creates an obligation for the community in order to protect the right to the health of others (the right of others to protect themselves from the transmission of COVID-19). ${ }^{11}$

Basically Vaccines are ${ }^{12}$ :

"Biological product containing antigens in the form of dead or alive microorganisms that are attenuated, still intact or parts thereof, or in the form of toxins from microorganisms that have been processed into toxoids or recombinant proteins, which are added with other substances, which when given to a person will cause specific immunity. actively against certain diseases."

Based on the definition of the vaccine, this COVID-19 vaccine contains antigens from the COVID-19 virus which is given with the aim of generating immunity to COVID-19 disease for people who receive the COVID-19 vaccine.

The government's efforts to fulfill its obligations to the community can be seen from the provision of free vaccines to the community which are distributed through health service facilities such as health centers, hospitals, central hospitals and state-owned hospitals ${ }^{13}$ and even in other places such as schools ${ }^{14}$, churches, foundations, Islamic boarding schools ${ }^{15}$, even in malls ${ }^{16}$ for people who attend only by bringing their ID cards. The government has brought in vaccines to meet national vaccination needs, both through bilateral and multilateral channels, so far it has reached the $61^{\text {st }}$ stage so that the total vaccine owned by Indonesia until September 2021 has reached more than 243 million doses of vaccine, both in finished form and raw

9 Article 1 paragraph (3) of the Regulation of the Minister of Health of the Republic of Indonesia Number 84 of 2020 concerning the Implementation of Vaccination in the Context of Combating the 2019 Corona Virus Disease (COVID-19) Pandemic.

10 Nyoman Ary Wahyudi, "Wamenkumham: Vaksinasi Covid-19 Suatu Kewajiban" https://kabar24.bisnis.com/read/20210116/16/1343847/wamenkumham-vaksinasi-covid-19-suatu-kewajiban, accessed at 7 September 2021.

11 “.... Everyone's rights, even including one's human rights, are limited by the existence of other people's rights”, Gandryani, F., \& Hadi, F. (2021). Pelaksanaan Vaksinasi Covid-19 Di Indonesia: Hak Atau Kewajiban Warga Negara. Jurnal Rechts Vinding: Media Pembinaan Hukum Nasional, 10(1), 23.

12 Pengertian vaksin berdasarkan pasal 1 ayat (1) Peraturan Menteri Kesehatan Republik Indonesia Nomor 84 Tahun 2020 tentang Pelaksanaan Vaksinasi dalam Rangka Penanggulangan Pandemi Corona Virus Disease 2019 (COVID-19)

13 Dian Erika Nugraheny, "Jubir: Vaksinasi Covid-19 Gratis di Fasilitas Kesehatan Pemerintah", https://nasional.kompas.com/read/2020/12/19/16375641/jubir-vaksinasi-covid-19-gratis-di-fasilitas-kesehatanpemerintah, accessed at 6 September 2021.

14 Budiarti Utami Putri, "Vaksinasi Anak 12-17 Tahun Bisa Dgelar di Sekolah, Madrasah, dan Pesantren", https://nasional.tempo.co/read/1478500/vaksinasi-anak-12-17-tahun-bisa-digelar-di-sekolah-madrasah-danpesantren, accessed at 6 September 2021

15 Misti Prihantini, "2000 Dosis Vaksinasi Serentak Pesantren dan Rumah Ibadah di Kota Mojokerto", https://beritajatim.com/pendidikan-kesehatan/2-000-dosis-vaksinasi-serentak-pesantren-dan-rumah-ibadah-dikota-mojokerto/, accessed at 7 November 2021

16 Feni Freycinetia Fitriani, "Lokasi Vaksinasi Covid-19 di Mal Jakarta, Cek Syarat dan Cara Daftarnya", https://jakarta.bisnis.com/read/20210905/77/1438164/lokasi-vaksinasi-covid-19-di-mal-jakarta-cek-syarat-dancara-daftarnya, accessed at 6 September 2021

404|S A S I Volume 27 Issue 4, October-December 2021 
materials. ${ }^{17}$

Vaccines that can be used for the implementation of vaccinations in Indonesia vary, including those produced by PT. Bio Farma (Persero), AstraZeneca, China National Pharmaceutical Group Corporation (Sinopharm), Moderna, Novavax Inc., Pfizer Inc., BioNTech, and Sinovac Life Sciences Co., Ltd. ${ }^{18}$ Although various types of COVID-19 vaccines have been provided, their function is the same, namely to form immunity against COVID-19. The government also promotes the motto "the best vaccine is the vaccine currently available" so that whatever type of COVID-19 vaccine is available, that is the choice for today's society. ${ }^{19}$

Apart from the benefits of the COVID-19 vaccine, many people think there is no need to get a vaccine for several reasons, including the spread of fake news or what is commonly called hoaxes. Hoaxes are understood as hoaxes or jokes (humorous or malicious deception) according to the Oxford Dictionary, while according to the Big Indonesian Dictionary online hoaxes are (1) untrue, lying (about news, messages and so on); (2) fake news. ${ }^{20}$

Various fake news that spread on social media about COVID-19 affect the public in responding to the government's efforts to spread the COVID-19 vaccine. Many people are affected by the fake news so they are reluctant and even refuse to be given the COVID-19 vaccine. The following is data regarding fake news spread through social media which was traced from January to December 2020.

Table 1.

List of News Suspected of Containing a COVID-19 Vaccine Hoax

\begin{tabular}{|c|c|c|c|}
\hline Data & Tanggal & Media & Hal \\
\hline 1. & 20 December 2020 & Twitter & $\begin{array}{l}\text { Nurse faints after being injected with COVID-19 } \\
\text { vaccine }\end{array}$ \\
\hline 2. & 16 December 2020 & Whatsapp & $\begin{array}{l}\text { Formaldehyde in Vaccines Causes Leukemia in } \\
\text { Children }\end{array}$ \\
\hline 3. & 7 December 2020 & Instagram & $\begin{array}{l}\text { Covid-19 Vaccine Planted with Barcodes that will } \\
\text { Enter the Human Body }\end{array}$ \\
\hline 4. & 27 November 2020 & Instagram & Vaksin mengandung Alumunium Bisa Merusak Otak \\
\hline 5. & 25 November 2020 & Instagram & Rakyat Indonesia akan Dibunuh Vaksin China \\
\hline 6. & 23 November 2020 & Instagram & $\begin{array}{l}\text { AstraZeneca's COVID-19 Vaccine Uses Abortion } \\
\text { Fetal Tissue }\end{array}$ \\
\hline
\end{tabular}

17 Humas, "Kedatangan 1,8 Juta Dosis Vaksin Sinovac, Pemerintah Pastikan Stok Vaksin Aman", https://setkab.go.id/kedatangan-18-juta-dosis-vaksin-sinovac-pemerintah-pastikan-stok-vaksin-aman/, accessed at 14 September 2021.

18 Keputusan Menteri Kesehatan Republik Indonesia Nomor HK.01.07/MENKES/12758/2020 tentang Penetapan Jenis Vaksin untuk Pelaksanaan Vaksinasi Corona Virus Disease 2019 (COVID-19) Diktum Kesatu.

19 Asep Firmansyah, "Vaksinolog: Vaksin terbaik adalah yang tersedia untuk disuntikkan, Berita Antara News, Selasa, 24 Agustus 2021, https://www.antaranews.com/berita/2347506/vaksinolog-vaksin-terbaik-adalahyang-tersedia-untuk-disuntikkan, accessed at 6 September 2021.

20 Arianto, A. K. (2021). Dugaan Hoaks Seputar Vaksin Covid-19 Di Indonesia Dalam Kerangka Linguistik Forensik. KoPeN: Konferensi Pendidikan Nasional, 3(1), 115-129.

405|SASI Volume 27 Issue 4, October-December 2021 


\begin{tabular}{|c|c|c|c|}
\hline 7. & 20 October 2020 & Instagram & COVID-19 Vaccine Can Change Human DNA \\
\hline 8. & 5 October 2020 & Instagram & $\begin{array}{l}\text { Luhut Takes COVID-19 Vaccine to China with the } \\
\text { Intention of Exterminating Natives }\end{array}$ \\
\hline 9. & 27 September 2020 & Facebook & China's Corona Vaccine Contain Pork \\
\hline 10. & 27 August 2020 & Instagram & Covid-19 Vaccine Causes Infertility \\
\hline 11. & 31 July 2020 & Facebook & $\begin{array}{l}\text { The Rockefeller Foundation is Behind the Emergence } \\
\text { of the Corona Covid-19 Virus }\end{array}$ \\
\hline 12. & 19 March 2020 & Facebook & Only Habib Rizieq Has Corona Virus Antidote \\
\hline 13. & 28 January 2020 & TikTok & Healing Corona Virus with Garlic \\
\hline
\end{tabular}

Source: Secondary Data, processed based on journal sources: Ahmad Khoironi Arianto, "Alleged Hoax Regarding the COVID-19 Vaccine in Indonesia in Forensic Linguistics Framework", Journal of the National Education Conference, Vol.3 No.1 (2021)

The data shows that the news circulating through social media contains a lot of negative news about the COVID-19 vaccine and tends to influence the public not to comply with the Government's recommendations for the COVID-19 vaccination, while with this vaccination the Government seeks to fulfill the people's right to obtain health services according to the constitution and this covid-19 vaccination is included in one of the health quarantine measures as stated in Article 15 paragraph (2) a of the KK Law ${ }^{21}$.

People who do not agree with or refuse the COVID-19 vaccine can use the legal basis of Article 5 paragraph (3) of the Health Law that everyone has the right to determine for themselves the health services needed for themselves, including accepting or refusing the COVID-19 vaccination. In this case the acceptance or rejection of the COVID-19 vaccination is considered a human right. However, when someone exercises their right to refuse vaccination, it can be considered that that person has crossed the limits of the other person's right to health, which requires protection with herd immunity which can be achieved after $70 \%$ of the population has received the vaccine injection. ${ }^{22}$ This is as stated in Article $28 \mathrm{~J}$ of the 1945 Constitution where everyone is obliged to respect the human rights of others. ${ }^{23}$

A person's refusal to vaccinate can also be considered a violation of his or her obligation to participate in a health quarantine program (article 9 paragraph (2) of the Health Law) ${ }^{24}$. What's more, people who do not obey the rules of law and officials who carry out the functions of the law, in this case the rules regarding COVID-19 vaccination will be subject to criminal sanctions in accordance with article 216 of the Criminal Code (KUHP). ${ }^{25}$

21 Article 15 paragraph (2) a of the KK Law stipulates that: "The Health Quarantine Measures as referred to in paragraph (2) are in the form of: a. Quarantine, Isolation, vaccination or prophylaxis, referral, disinfection, and/or decontamination of people according to indications;

22 Hanni Sofia, "Vaksinasi, antara hak dan kewajiban warga negara", https://www.antaranews.com/berita/1943320/vaksinasi-antara-hak-dan-kewajiban-warga-negara, accessed at 18 September 2021.

23 Article $28 \mathrm{~J}$ (1) of the 1945 Constitution states that "Everyone is obliged to respect the human rights of others in the orderly life of society, nation and state."

24 Article 9 paragraph (2) of the KK Law states that: "Everyone is obliged to participate in the implementation of health quarantine"

${ }^{25}$ Article 216 of the Criminal Code: "Anyone who intentionally disobeys orders or requests made according to the law by an official whose task is to supervise something, or by an official based on his duties, as well as those who are authorized to investigate or examine criminal acts; Likewise, any person who intentionally prevents,

406|S A S Volume 27 Is u e 4, October-December 2021 
In the end, the fake news created obstacles to enforcement of regulations regarding COVID-19 vaccination, where the objectives of the rules regarding the handling of COVID-19, both according to the KK Law and the Health Law, could be realized by reducing COVID-19 cases, although currently in some areas has decreased, but for the whole of Indonesia, confirmed cases have actually increased by 3,385 cases as of 19 September $2021 .^{26}$

Therefore, the Indonesian government stipulates that the spread of fake news can be punished according to Law no. 19 of 2016 concerning Amendments to Law No. 11 of 2008 concerning Information and Electronic Transactions (UU ITE) ${ }^{27}$. Efforts to deal with fake news include the police intensifying cyber patrols and getting 41 cases of perpetrators spreading fake news about COVID-19 in Indonesia on March 23, 2020. ${ }^{28}$

For this reason, the government urges the public to be more careful in receiving information. The public should sort and filter information so that people do not fall into untrue news. In this case, it is important to carry out digital literacy through official articles on the internet and through official information or news on the official website. This is very important to avoid vaccine rejection which results in not achieving the vaccination goal for fulfilling the health rights of the entire community and leading to criminal threats.

\section{CONCLUSION}

The government has tried to deal with the Covid-19 pandemic which continues to increase with Covid-19 vaccinations for all Indonesian people, but there are still many people who spread fake news so that public acceptance of vaccines creates pros and cons. This fake news will thwart the purpose of spreading vaccines, namely the protection of the right to health of all people. Spreaders of fake news will be subject to criminal sanctions. The public is urged to be more careful by sorting and filtering all information received so as not to fall into fake news and to avoid vaccination refusals that lead to criminal threats.

\section{REFERENCES}

\section{Journal}

[1] Arianto, A. K. (2021). Dugaan Hoaks Seputar Vaksin Covid-19 Di Indonesia Dalam Kerangka Linguistik Forensik. KoPeN: Konferensi Pendidikan Nasional, 3(1), 115-129.

[2] Chumairoh, H. (2020). Ancaman Berita Bohong di Tengah Pandemi Covid-19. Vox Populi, 3(1), 22-30.

[3] Gandryani, F., \& Hadi, F. (2021). Pelaksanaan Vaksinasi Covid-19 Di Indonesia: Hak Atau Kewajiban Warga Negara. Jurnal Rechts Vinding: Media Pembinaan Hukum Nasional, 10(1), 23.

[4] Kunarso, K., \& Sumaryanto, A. D. (2020). Eksistensi Perjanjian Ditengah Pandemi Covid19. Batulis Civil Law Review, 1(1), 33-46.

[5] Pratama, A. M. (2021, July). Pemenuhan Vaksinasi Covid-19 sebagai Hak atas Kesehatan bagi Masyarakat Adat di Indonesia. In Seminar Nasional Hukum Universitas Negeri Semarang (Vol. 7, No. 1, pp. 219-236).

[6] Saija, R., \& Sudiarawan, K. A. (2021). Perlindungan Hukum Bagi Perusahaan Debitur Pailit dalam Menghadapi Pandemi Covid 19. Batulis Civil Law Review, 2(1), 66-77.

[7] Taun, T., \& Nugraha, A. (2020). Penerapan Hukum dalam Pemutusan Hubungan Kerja dan

\footnotetext{
hinders or thwarts an action to carry out the provisions of the law carried out by one of these officials, is threatened with a maximum imprisonment of four months and two weeks or a maximum fine of nine thousand rupiahs.

26 https://covid19.go.id/peta-sebaran, accessed at 19 September 2021

27 Pencemaran nama baik atau fitnah (pasal 27 ayat (3)), penipuan untuk motif ekonomi yang merugikan konsumen (pasal 28 ayat (1)), provokasi terkait sara (pasal 28 ayat 2)

${ }_{28}$ Chumairoh, H. (2020). Ancaman Berita Bohong di Tengah Pandemi Covid-19. Vox Populi, 3(1), 22-30. 407|S A I Volume 27 Is u e 4, October-December 2021
} 
Kebijakan Bank Terhadap Debitur yang Terdampak Pandemi Covid-19. Batulis Civil Law Review, 1(1), 24-32.

\section{Online/World Wide Web, Thesis etc}

[8] Ariati Dewi, Radhiya Bustan, "Sosialisasi Vaksinasi COVID-19 dan Protokol Kesehatan 7 M Sebagai Upaya Pencegahan Penyebaran Virus COVID-19”, Artikel Hasil Pengabdian kepada Masyarakat, Seminar Nasional Penelitian dan Pengabdian kepada Masyarakat) Tahun 2021, h. 1, https://repository.ummetro.ac.id/files/artikel/3288.pdf, accessed at 12 September 2021.

[9] Asep Firmansyah, "Vaksinolog: Vaksin terbaik adalah yang tersedia untuk disuntikkan, Berita Antara News, Selasa, 24 Agustus 2021, https://www.antaranews.com/berita/2347506/vaksinolog-vaksin-terbaik-adalah-yangtersedia-untuk-disuntikkan.

[10] Budiarti Utami Putri, "Vaksinasi Anak 12-17 Tahun Bisa Dgelar di Sekolah, Madrasah, dan Pesantren”, https://nasional.tempo.co/read/1478500/vaksinasi-anak-12-17-tahun-bisadigelar-di-sekolah-madrasah-dan-pesantren.

[11]Dian Erika Nugraheny, "Jubir: Vaksinasi Covid-19 Gratis di Fasilitas Kesehatan Pemerintah", https://nasional.kompas.com/read/2020/12/19/16375641/jubir-vaksinasicovid-19-gratis-di-fasilitas-kesehatan-pemerintah.

[12]Feni Freycinetia Fitriani, "Lokasi Vaksinasi Covid-19 di Mal Jakarta, Cek Syarat dan Cara Daftarnya”, https://jakarta.bisnis.com/read/20210905/77/1438164/lokasi-vaksinasi-covid19-di-mal-jakarta-cek-syarat-dan-cara-daftarnya.

[13]Hanni Sofia, "Vaksinasi, antara hak dan kewajiban warga negara", https://www.antaranews.com/berita/1943320/vaksinasi-antara-hak-dan-kewajiban-warganegara.

[14]Humas, "Kedatangan 1,8 Juta Dosis Vaksin Sinovac, Pemerintah Pastikan Stok Vaksin Aman", $\quad$ https://setkab.go.id/kedatangan-18-juta-dosis-vaksin-sinovac-pemerintahpastikan-stok-vaksin-aman/.

[15] Misti Prihantini, "2000 Dosis Vaksinasi Serentak Pesantren dan Rumah Ibadah di Kota Mojokerto", $\quad$ https://beritajatim.com/pendidikan-kesehatan/2-000-dosis-vaksinasiserentak-pesantren-dan-rumah-ibadah-di-kota-mojokerto/

[16] Nyoman Ary Wahyudi, "Wamenkumham: Vaksinasi Covid-19 Suatu Kewajiban" https://kabar24.bisnis.com/read/20210116/16/1343847/wamenkumham-vaksinasi-covid19-suatu-kewajiban.

[17]Raines Wadi, "Keharusan Vaksin dan Hak atas Kesehatan", https://news.detik.com/kolom/d-5333213/keharusan-vaksin-dan-hak-atas-kesehatan. 